\title{
ГЕОГРАФИЯ
}

УДК 631.48

DOI: $10.18101 / 2542-0623-2019-3-54-61$

\section{ВЛИЯНИЕ КУЧИГЕРСКИХ ГИДРОТЕРМ НА СОДЕРЖАНИЕ И ФОРМЫ НАТРИЯ (БАРГУЗИНСКАЯ КОТЛОВИНА)}

\author{
Т. А. Аюшина \\ (C) Аюшина Туяна Аюшиевна \\ кандидат биологических наук, \\ Институт общей и экспериментальной биологии СО РАН \\ Россия, 670047, г. Улан-Удэ, ул. Сахьяновой, 6 \\ E-mail: tuyana2602@mail.ru
}

Изучено содержание разных форм натрия в почвах, находящихся в зоне влияния Кучигерского минерального источника (север Байкальской рифтовой зоны). Установлено, что среднее содержание натрия в термальных источниках, породах и почвах находится выше уровня кларков. Высокие показатели натрия в почвах Баргузинской котловины обусловлены сочетанием эндогенных (разгрузка гидротерм и выходы флюидов) и экзогенных (резко континентальный климат, почвообразующие породы - щелочные граниты) факторов. Установлены особенности пространственного и профильного распределения натрия в почвах. Этот элемент может использоваться при почвенно-экологическом мониторинге, необходимом в почвах рифтовых зон с аномально высокими концентрациями поступающих веществ с термальными водами.

Ключевые слова: Баргузинская котловина; эндогенез; засоление; натрий; почвы.

\section{Для цитирования}

Аюшина T. А. Влияние кучигерских гидротерм на содержание и формы натрия (Баргузинская котловина) // Природа Внутренней Азии. Nature of Inner Asia. 2019. № 3(12). C. 54-61. DOI: 10.18101/2542-0623-2019-3-54-61

\section{Введение}

Ведущая роль в биологическом и геохимическом круговороте принадлежит натрию. Этот химический элемент участвует в минеральном обмене всех живых организмов, поддерживает солевой и водный баланс. Недостаток и особенно избыток ионов натрия негативно сказываются на жизнедеятельности организмов, растительности, вызывая токсичность.

Натрий является шестым по распространенности элементом в земной коре, его кларк составляет 2,64\%. Натрий содержится во всех материнских породах: в кислых изверженных породах - 2,77\%, в основных - 1,94\%, в ультраосновных - 0,57\%. Осадочные породы резко обеднены натрием: содержание в глинах и сланцах — 0,96-0,66\%, в песчаниках — 0,33\% [Добровольский, 2009]. Минеральные виды натрия по генезису на 70\% магматические или термальные и на 
$30 \%$ гипергенные образования. Известно свыше 220 минералов, в составе которых присутствует натрий: полевые шпаты, плагиоклазы, галит ( $\mathrm{NaCI})$, чилийская селитра $\mathrm{NaNO}_{3}$, тенардит $\mathrm{Na}_{2} \mathrm{SO}_{4}$, мирабилит, или глауберова соль, $\mathrm{Na}_{2} \mathrm{SO}_{4} \cdot 10 \mathrm{H}_{2} \mathrm{O}$, сильвинит $\mathrm{KCI} \cdot \mathrm{NaCI}$ и другие.

Натрий - очень подвижный элемент, слабо задерживающийся на трансэлювиальных, трансаккумулятивных ландшафтах. В большинстве незасоленных почв валовое содержание натрия невысокое (при среднем значении $0,63 \%$ ). В основном осаждение солей натрия происходит в приморских лагунах, в континентальных озерах степей и пустынь, в зонах разгрузок минерализованных вод, и поэтому натрий является типоморфным элементом этих территорий [Касимов, 1980; Перельман, 1972]. Высокое содержание натрия обусловливает неблагоприятные физические и химические свойства почв и их засоление.

Территория Байкальской рифтовой зоны (БРЗ) характеризуется многочисленными разрывными нарушениями, по которым происходит разгрузка термальных вод и выходы газовых флюидов. Кучигерские гидротермы разгружаются в северо-западной части Баргузинской впадины на правом берегу реки Баргузин в урочище Кучигер и насчитывают 17 выходов терм с температурой воды до $40{ }^{\circ} \mathrm{C}$ [Чернявский и др., 2018]. Под воздействием минеральных вод формируется галоморфный ландшафт с комплексом засоленных почв, в составе которых резко доминирует натрий.

В настоящее время имеются фрагментарные научные работы по количественным и качественным оценкам содержания натрия в почвах Западного Забайкалья [Меркушева и др., 2011; Убугунов и др., 2012], а о содержании натрия в почвах зон тектонических разломов БРЗ данные практически отсутствуют.

\section{Цель}

Изучить накопление и распределение форм натрия в почвах, формирующихся в зонах разгрузки термальных вод с повышенным содержанием этого элемента.

\section{Объекты и методы}

Объектами исследований явились засоленные почвы Баргузинской котловины в зоне тектонических разломов с активным выходом термальных вод. Климат этого района резко континентальный. Почвообразующие породы предгорной наклонной равнины Баргузинского и Улюнского хребтов представлены делювиально-элювиальными отложениями щелочных гранитов Ангаро-Витимского батолита [Носков, 2011]. Степные плосковершинные возвышенности сложены мощной толщей кварц-полевошпатовых полимиктовых песков.

Разгружающиеся термальные воды маломинерализованые (до 1 мг/л), по составу азотно-кремнистые фтористые гидрокарбонатно-сульфатно-натриевые, имеют щелочной $\mathrm{pH}$. Содержание натрия в Кучигерских гидротермах составляет 117000 мкг/л, что в 26 раз выше кларка речных вод (табл. 1). 
Содержание $\mathrm{Na}$ в термальных водах Кучигерского источника, кларки речных вод, мкг/л

\begin{tabular}{|c|c|c|c|c|}
\hline \multirow{2}{*}{$\begin{array}{c}\text { Кучигерские гидро- } \\
\text { термы [Чернявский, } \\
2006]\end{array}$} & \multirow{2}{*}{$\begin{array}{c}\text { Кларк } \\
\text { речных вод } \\
\text { Добровольский, } \\
\text { 2009] }\end{array}$} & \multirow{2}{*}{$\begin{array}{c}\text { Кларк вод } \\
\text { зоны активного } \\
\text { водообмена } \\
\text { [Перельман, 1979] }\end{array}$} & \multicolumn{2}{|c|}{ Отношение к } \\
\hline & & & $\begin{array}{c}\text { кларку } \\
\text { речных вод }\end{array}$ & $\begin{array}{c}\text { кларку вод } \\
\text { зоны активного } \\
\text { водообмена }\end{array}$ \\
\hline 117000 & 4500 & 13800 & 26 & 8,5 \\
\hline
\end{tabular}

Было отобрано и проанализировано 273 почвенных образцов. Объектами исследования были торфяно-перегнойно-глеевые почвы в непосредственной близости от выходов газогидротермальных источников; псаммоземы гумусовые импрегнированные, возникшие в результате локального подъема поверхности и выдавливания песчано-пылеватого материала на поверхность под давлением восходящих флюидов; прилегающие к болоту аллювиальные светлогумусовые импрегнированные газогидротермально турбированные почвы. Всем этим почвам характерны морфологические особенности в виде турбированности, наличия в почвенном профиле специфических черных импрегнированных вязкопластичных слоев, пятен.

Физико-химические анализы почв выполнены общепринятыми методами [Аринушкина, 1970], активности ионов натрия в почвенной пасте с влажностью $30 \%$ измерены ионоселективными электродами ЭЛИС на приборе Экотест-120, водорастворимый натрий из водной вытяжки (1:5), валовой натрий - после разложения почвы фтористоводородной кислотой атомно-эмиссионным методом на спектрометре SPECTRO ARCOS.

\section{Обсуждение и результат}

Химический и минералогический составы почвообразующих пород во многом определяют содержание макро- и микроэлементов в почве. Основными продуктами выветривания щелочных гранитов Ангаро-Витимского батолита в Баргузинской котловине являются кварц-полевошпатовые полимиктовые пески [Убугунов, Убугунова, 2017]. Количество натрия в них составляет $2,4-2,5 \%$, а величина $\mathrm{Na} / \mathrm{K}$ равна $1,8-1,9$, т. е. сами граниты относятся к калиево-натриевой серии [Горная... 1987]. В почве натрий присутствует главным образом в составе натрийсодержащих первичных минералов - калиево-натриевых (щелочных) и кальциево-натриевых (плагиоклазы) полевых шпатах. Их доля в верхней части земной коры составляет около $50 \%$ ее массы, или $60-65 \%$ объема.

В районе исследований с разгружающимися термальными водами в почву поступает значительное количество натрия. Одну из причин высокого количества натрия связывают с большой глубиной (3-5 км) тектонических разломов БР3 и выходом максимального теплового потока, активизирующих поступление к поверхности газогидротермальных флюидов. В этих условиях азотные термы образуют с горными породами равновесную систему, при которой в условиях 
высоких рН осаждаются карбонатные минералы и накапливаются $\mathrm{Si}, \mathrm{Na}, \mathrm{K}, \mathrm{F}$ [Плюснин и др., 2013]. Также в термальных водах выявлено превышение ряда химических элементов: натрия, серы, стронция, бария, лития, кремния, фтора, титана, калия [Чернявский, 2006; Shartsev et. al., 2015].

Кучигерские термальные воды оказывают большое воздействие на почвы, находящиеся в зоне их активной разгрузки. Болотные почвы как первичный коллектор газогидротермальных источников не замерзают круглый год, но в периферийной части болота ближе к берегу до середины июня наблюдались сезонно-мерзлые горизонты. Поступление теплых слабоминерализованных $(0,4-0,6$ г/л) гидрокарбонатно-сульфатно-натриевых подземных вод и восстановительные условия болота способствуют активной сульфатредукции за счет микробиологической деятельности с образованием сероводорода, в почве отмечается множество мелких кристаллов пирита $\left(\mathrm{FeS}_{2}\right)$ в песчаных глеевых горизонтах. Глеевые горизонты часто имеют черную окраску за счет импрегнирования снизу предположительно конденсированным органическим веществом. Прилегающие к болоту светлогумусовые газогидротермально турбированные почвы характеризуются сильно турбированным профилем, наличием импрегнированных горизонтов, слоев и линз, вызванных действием газогидротермальных флюидов. Почвы имеют сильнощелочную реакцию среды $(\mathrm{pH}>8,5)$, солевые корочки на поверхности и засолены по всему профилю.

Валовое содержание натрия отражает его общий резерв в почве. В исследуемых почвах общий резерв натрия высокий (табл. 2).

Валовое содержание в большей степени определяется содержанием песчаных фракций, в которых натрий содержится в кристаллической решетке минералов. Количество валового натрия в почвенном профиле (кроме солевой корочки) колеблется в пределах 23 165-33 051 мг/кг, это в 1,5 раза выше содержания его в земной коре (Кларк 20700 мг/кг), в 2 раза выше, чем в классических гранитах (14 252 мг/кг), и приблизительно одинаково с Ангаро-Витимским батолитом (29 457 мг/кг).

Высокие значения натрия отмечены в почвах, имеющих в профиле импрегнированные горизонты скопления газогидратных выходов: аллювиальная светлогумусовая импрегнированная, аллювиальная гумусово-слаборазвитая импрегнированная, псаммозем гумусовый импрегнированный. В этих почвах происходит накопление валового натрия, что подтверждает эллювиальноаккумулятивный коэффициент - отношение концентрации натрия в генетическом горизонте почвы к его количеству в материнской породе (Каэ больше 1). Относительно низкие значения валового натрия — в торфяно-перегнойно-глеевой почве, здесь отмечается накопление только в нижележащих горизонтах (Каэ меньше 1).

Среднее содержание валового натрия в почвах зоны влияния Кучигерских гидротерм на 10\% выше, чем в среднем в солончаках Баргузинской котловины, и почти втрое выше регионального фона, что подтверждает активное влияние гидротерм на его накопление в почвенном покрове [Жамбалова, 2018]. 
Содержание $\mathrm{Na}$ в почвах, формирующихся в зоне активной разгрузки термальных вод

\begin{tabular}{|c|c|c|c|c|c|}
\hline Почва & $\begin{array}{l}\text { Горизонт, } \\
\text { глубина, см }\end{array}$ & $\begin{array}{c}\mathrm{Na} \\
\text { валовой, } \\
\text { мг/кг }\end{array}$ & $\begin{array}{l}\text { Na водораств., } \\
\text { смоль(ЭКв)/кг }\end{array}$ & $\begin{array}{c}\text { a Na, } \\
\text { ммоль/л }\end{array}$ & $\mathrm{a}_{\mathrm{Na}} / \sqrt{ } \mathrm{a}_{\mathrm{Ca}}$ \\
\hline \multirow{6}{*}{$\begin{array}{c}\text { РФ-1-3 } \\
\text { Торфяно- } \\
\text { перегнойно-глеевая }\end{array}$} & $0-20$ & 2921 & 6,52 & 1,66 & 3,1 \\
\hline & $20-40$ & 4226 & 7,83 & 4,37 & 7,7 \\
\hline & $40-80$ & 23165 & 13,30 & 5,89 & 27,8 \\
\hline & $90-120$ & 24747 & 12,26 & 6,61 & 27,0 \\
\hline & $120-160$ & 25854 & 11,30 & 7,94 & 30,2 \\
\hline & $160-190$ & 25854 & 15,43 & 6,46 & 25,7 \\
\hline \multirow{7}{*}{$\begin{array}{c}\text { РФ-1-4 } \\
\text { Псаммозем } \\
\text { гумусовый } \\
\text { импрегнированный }\end{array}$} & $0-1,5$ & 26306 & 13,0 & 5,37 & 28,3 \\
\hline & $1,5-6(7)$ & 27922 & 9,74 & 9,55 & 174,4 \\
\hline & $\begin{array}{c}\text { 6(7)-40(41) } \\
\text { темный }\end{array}$ & 27968 & 29,13 & 21,38 & 81,4 \\
\hline & $\begin{array}{c}\text { 6(7)-40(41) } \\
\text { светлый }\end{array}$ & 30906 & 5,87 & 8,71 & 194,8 \\
\hline & $40(41)-85$ & 28939 & 6,22 & 5,62 & 20,0 \\
\hline & $85-105$ & 28313 & 8,48 & 3,47 & 9,8 \\
\hline & $105-165$ & 29351 & 7,96 & 5,50 & 25,5 \\
\hline \multirow{8}{*}{$\begin{array}{c}\text { РФ-1-5 } \\
\text { Аллювиальная } \\
\text { светлогумусовая } \\
\text { импрегнированная }\end{array}$} & Корка & 58671 & 35,70 & не опр. & \\
\hline & $0-6$ & 28705 & 21,57 & 85,11 & 1903,1 \\
\hline & $6-20(41)$ & 31387 & 5,39 & 3,16 & 99,9 \\
\hline & $6(41)-55$ & 28270 & 1,96 & 4,68 & 49,3 \\
\hline & $55-75$ & 27210 & 2,78 & 0,85 & 3,8 \\
\hline & $75-95$ & 27041 & 2,17 & 5,62 & 51,3 \\
\hline & $95-135$ & 28641 & 3,26 & 10,0 & 91,3 \\
\hline & $135-155$ & 28419 & 1,74 & 6,31 & 39,9 \\
\hline \multirow{9}{*}{$\begin{array}{c}\text { РФ-1-7 } \\
\text { Аллювиальная } \\
\text { гумусово- } \\
\text { слаборазвитая } \\
\text { импрегнированная }\end{array}$} & корка & 24592 & 5,43 & не опр. & \\
\hline & $0-7$ & 26648 & 4,35 & 22,91 & 75,9 \\
\hline & $7-30$ & 29394 & 3,91 & 14,13 & 93,2 \\
\hline & $30-50$ & 26542 & 1,30 & 16,98 & 79,2 \\
\hline & $50-70$ & 28069 & 1,30 & 8,32 & 39,2 \\
\hline & $70-75$ & 27316 & 1,30 & 4,27 & 14,0 \\
\hline & $80-100$ & 27125 & 1,26 & 5,89 & 25,3 \\
\hline & $100-120$ & 28588 & 1,61 & 3,55 & 29,0 \\
\hline & $120-140$ & 24475 & 1,39 & 4,17 & 14,3 \\
\hline
\end{tabular}

Все исследуемые почвы засолены, по степени засоления варьируют от слабодо сильнозасоленных. Тип засоления преимущественно сульфатно-натриевый и аналогичен составу минеральных вод Кучигерского источника. Количество водорастворимого натрия является непосредственным резервом содержания натрия в почве. Эта доля натрия максимальна в засоленных почвах. Доля водорастворимой формы натрия в изученных почвах колебалась в значительном диапазоне - от 1,3 до 35,7 смоль/кг. Профильное распределение водорастворимого натрия в почвах 
T. А. Аюшина. Влияние кучигерских гидротерм на содержание и формы натрия (Баргузинская котловина)

показывает более контрастное испарительное накопление элемента в легких почвах с активным аллювиальным синлитогенезом и менее контрастное - в тяжелых, выходящих из-под влияния поемности. Натрий осаждается на испарительном и сорбционном барьерах засоленных почв, а в целом накопление натрия носит неоднородный пульсирующий характер (рис. 1).
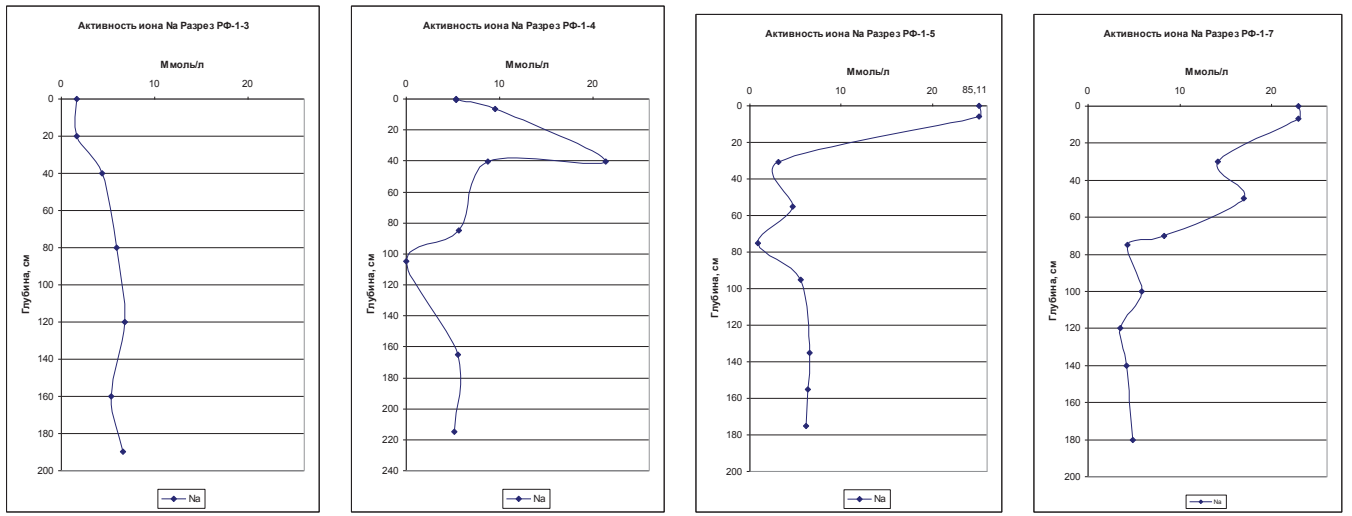

Puc. 1. Вертикальное распределение активности ионов натрия при влажности пасты $30 \%$ (Трансект-1)

Натрий очень подвижен в любой геохимической обстановке и распределяется по профилю почв неравномерно. В болотных почвах натрий накапливается преимущественно в нижележащих горизонтах. Количество водорастворимого натрия в торфяно-перегнойно-глеевой почве составляет 11,3-15,5 смоль/кг, в аллювиальных почвах его содержание варьирует в более широком диапазоне от 1,3 до 21,6 смоль/кг. Однако в более аридных условиях за счет испарительной концентрации происходит накопление легкорастворимых солей в поверхностных горизонтах в псаммоземах и аллювиальных светлогумусовых почвах, где в поверхностных горизонтах содержание водорастворимой формы натрия доходит до 35,7 смоль/кг. Проявляется тесная связь токсичных солей с натрием. В аллювиальной светлогумусовой почве содержание токсичных солей в верхнем 0-20 см слое достигает $1,7 \%$, здесь активность ионов натрия очень высокая - 85 ммоль/л, активность ионов кальция крайне низкая и отношение $\mathrm{a}_{\mathrm{Na}} / \mathrm{a}_{\mathrm{Ca}}$ максимальное, обеспечивающее накопление обменного натрия в ЕКО выше токсичного уровня (табл. 2).

Натрий коррелирует со всеми фракциями гранулометрического состава, отмечается прямая связь с песчаными фракциями, особенно крупным и средним песком. Поэтому в легких опесчаненных почвах Баргузинской котловины содержание натрия высокое.

\section{Заключение}

Одним из основных типоморфных элементов засоления почв, формирующихся в местах разгрузки термальных вод, является натрий. Высокие показатели натрия в почвах Баргузинской котловины обусловлены сочетанием эндогенных (разгрузка гидротерм) и экзогенных (затрудненного стока, резко континентального климата 
и почвообразующих пород - щелочных гранитов) факторов. Для изученных почв характерно наличие в почвах импрегнированных горизонтов, линз, пятен, возможно, образованных в результате насыщения почвенных слоев восходящими углеводородными флюидами и являющихся дополнительным источником накопления натрия. В таких морфонах отмечаются повышенные содержания валового и водорастворимого натрия, высокие значения активности натрия, фтора, лития, бария, стронция, что свидетельствует об эндогенном источнике поступления этого элемента. Полученные материалы могут использоваться при почвенно-экологическом мониторинге, который необходимо проводить в почвах рифтовых зон с аномально высокими концентрациями поступающих веществ с термальными водами.

Работа выполнена при финансовой поддержке гранта РФФИ № 18-0400454 А и средств бюджета по теме «Эволюиия, функиионирование и экологобиогеохимическая роль почв Байкальского региона в условиях аридизаиии и опустынивания, разработка методов управления их продуктивныли процессами», № AAAA-A17-117011810038-7.

\section{Литература}

Агрохимические методы исследования почв. М.: Наука, 1975. 656 с.

Горная энциклопедия / гл. ред. Е. А. Козловский. М.: Сов. энциклопедия. 1984-1991. Т. 3. Кенган. Орт. 1987. 592 с.

Добровольский В. В. Биогеохимия мировой суши. Избранные труды. М.: Научный мир, 2009. Т. 3.439 с.

Жамбалова А. Д. Засоленные почвы зон разломов Кучигерских гидротерм: автореф. дис...канд. биол. наук. Улан-Удэ, 2018. 22 с.

Касимов Н. С. Геохимия ландшафтов зон разломов (на примере Казахстана). М.: Изд-во Моск. ун-та, 1980. 119 с.

Касимов Н. С., Власов Д. В. Кларки химических элементов как эталоны сравнения в экогеохимии // Вестник Московского университета. Сер. География. 2015. № 2. С. 7-17.

Меркушева М. Г., Убугунов Л. Л., Андреева И. М., Балданова А. Л. Натрий в системе почва - растение пойменных лугов Западного Забайкалья // Вестник БГСХА. 2011. № 4. C. $37-43$.

Носков Д. А. Геохимические особенности и условия образования Ангаро-Витимского гранитоидного батолита. Иркутск, 2011. 204 с.

Перельман А. И. Геохимия элементов в зоне гипергенеза. М.: Недра, 1972. 288 с.

Перельман А. И. Геохимия природных вод. М.: Наука, 1979. 150 с.

Плюснин А. М., Замана Л. В., Шварцев С. Л., Токаренко О. Г., Чернявский М. К. Гидрогеохимические особенности состава азотных терм Байкальской рифтовой зоны // Геология и геофизика, 2013. № 5. С. 647-664.

Убугунов В. Л. Убугунова В. И. Почвообразующие породы - ключ к пониманию самобытности почвообразования в Западном Забайкалье // Природа Внутренней Азии. 2017. № 4(5). C. 25-39.

Убугунов Л. Л., Андреева И. М., Меркушева М. Г. Агрохимическая оценка хлорида натрия как удобрения естественных пойменных травостоев Западного Забайкалья // Агрохимия. 2012. № 3. С. 32-40.

Цеховский Ю. Г., Балуев А. С., Стукалова И. Е., Корнева Р. Г. Седиментогенез в мезозойских и кайнозойских рифтовых впадинах Центральной Азии. М.: ГЕОС, 2018. 156 с. 
T. А. Аюшина. Влияние кучигерских гидротерм на содержание и формы натрия

(Баргузинская котловина)

Чернявский М. К., Плюснин А. М., Дорошкевич С. Г., Будаев Р. Ц. Рекреационно-бальнеологические особенности северо-восточной части Баргузинской котловины // География и природные ресурсы. 2018. № 2. С. 63-72.

Чернявский М. К. Геоэкологические особенности термальных источников Баргузинского Прибайкалья и использование их в бальнеологических целях: автореф. дис. ... канд. географ. наук. Улан-Удэ, 2006. 22 с.

Shvartsev S. L., Zamana L. V., Plyusnin A. M., Tokarenko O. G. Equilibrium of NitrogenRich Spring Waters of the Baikal Rift Zone with Host Rock Minerals as a Basis for Determining Mechanisms of Their Formation // Geochemistry International. 2015. V. 53. No. 8. P. 713-725.

\section{INFLUENCE OF KUCHIGER HYDROTHERM}

ON THE CONTENT AND FORMS OF SODIUM (BARGUZIN BASIN)

\section{T. A. Ayushina}

Tuyana A. Ayushina

Cand. Sci. (Biol.),

Institute of General and Experimental Biology SB RAS

6 Sakhyanovoy St., Ulan-Ude 670047, Russia

E-mail: tuyana2602@mail.ru

The article studies the content of various forms of sodium in soils near Kuchiger mineral spring (north of the Baikal rift zone). It was found that the average sodium content in thermal springs, rocks and soils is above the level of clarkes. High sodium indices in the soils of the Barguzin Basin are associated with a combination of endogenous (hydrothermal discharge and fluid yields) and exogenous (extreme continental climate, alkaline granites as parent rock material) factors. We have established the features of spatial and profile distribution of sodium in soils. This element can be used in soil ecological monitoring, necessary for the soils of rift zones with abnormally high concentrations of substances incoming from thermal waters.

Keywords: the Barguzin Basin; endogenesis; salinization; sodium; soils. 